\title{
Western Blot Analysis to Detect Cross-reaction in Toxocara vitulorum Protein with Anti-Mecistocirrus digitatus Serum
}

\author{
Desy Meta Anggraini ${ }^{1}$, Ir.H Kusnoto ${ }^{1 *}$, and Suryanie Sarudji ${ }^{2}$ \\ ${ }^{1}$ Department of Veterinary Parasitology, Faculty of Veterinary Medicine, Universitas Airlangga, Surabaya, East Java, Indonesia \\ ${ }^{2}$ Department of Veterinary Microbiology, Faculty of Veterinary Medicine, Universitas Airlangga, Surabaya, East Java, Indonesia \\ *Corresponding author's Email: kk.kusnoto@yahoo.com; (i) ORCiD: 0000-0003-3460-8105
}

\begin{abstract}
Worm infections are found in livestock and can be transmitted to humans. Toxocara vitulorum is a worm species which commonly infected people. Cross-reaction among worms can generate false positive to establish helminthiasis diagnosis through antibody inspection. This study aimed to determine specific proteins that caused cross-reaction between Toxocara vitulorum antigen and anti-M. digitatus serum by using the western blot technique. In the present study, the whole worms extracted of $\mathrm{T}$. vitulorum and $\mathrm{M}$. digitatus have been used to make polyclonal antibodies from M. digitatus with Wistar rats as hosts. The cross-reaction between whole worm extract of T. vitulorum protein and anti-M. digitatus serum obtained 12 protein bands that each relative molecular mass (Mr) valued of 176,124 , $92,68,59,47,31,29,26,16,12$, and $10 \mathrm{kDa}$. Cross-reaction occurred between $T$. vitulorum protein and anti- $M$. digitatus.
\end{abstract}

Key words: Cross-reaction, Mecistocirrus digitatus, Specific protein, Toxocara vitulorum, Western blot

\section{INTRODUCTION}

Worm infections can decrease productivity and cause inefficiency on livestock (Rast et al., 2014). The disease that causes low meat production is digestive tract infection by parasite worms, including Toxocara vitulorum worm, which can infect cows and buffalos (Mufidah et al., 2013).

Toxocariasis is a zoonotis disease because the larvae can cause Visceral larvae migrans and Ocular larva migrans in people. It can cause permanent eye damage in humans (De Souza et al., 2004). The larvae of T. vitulorum can be transmitted through colostrum and milk. The second larva becomes dormant in the non-definitive host. As the larvae migrate to the host system, it would be difficult to be diagnosed and controlled (Wickramasinghe et al., 2009).

Mecistocirrus digitatus is a blood-sucking cattle nematode located in the abomasum of infected ruminants and causing severe micro- and macroscopic lesions such as mucosal inflammation, hemorrhage, ulcers, and necrosis. The high pathogenicity of this nematode generates important losses in the cattle industry. Mecistocirrus digitatus has a wide distribution in Asia, Central, and northern South America, occurring mainly in young cattle (Fernex et al., 2014).

Each relative molecular mass (Mr) of Mecistocirrus digitatus protein profile were 107.74, 72.88, 64.68, 51.39, $47.1,43.52,38.55,36.27,32.97,28.95,25.8,23.25,20.95,15.65,12.85$, and $9.93 \mathrm{kDa}$. On the other hand, the $T$. vitulorum protein profile were 224, 227, 198, 155, 104, 87, 73, 67, 58, 55, 51, 48, 43, 37, 26, 16, 13, and $11 \mathrm{kDa}$ (Nugroho, 2012). Mecistocirrus digitatus and T. vitulorum proteins with the same Mr were 73, 51, 43, 26, 16, and 13 $\mathrm{kDa}$. The protein diversity might cause cross-reaction; it is about those antibodies that could react with more than one antigenic determinant. The epitope-specific antibody could bind other epitopes that are not related but have the same structure. The concept of antigen-antibody bonds is similar to keys and padlocks that are mutually bound (Mayer, 2010).

Worm antigens injected into animals could affect the immune response and stimulate animal antibodies (Darmawi et al., 2013). Western blot has 3 methods such as nitrocellulose membrane used to bind nonspecific antibody, primary antibody for incubating process and secondary antibody used to antigen-antibody reaction (Irnidayanti et al., 2018; Lastuti et al., 2018). This study was conducted to determine the specific proteins that caused cross-reaction between $T$. vitulorum antigens and anti- $M$. digitatus serum by using the western blot technique.

\section{MATERIALS AND METHODS}

\section{Ethical approval}

All experimental protocols and procedures were approved by the Institutional Animal Care of Indonesia. 
The present study was conducted from December 2016 until April 2017 in Faculty of Veterinary Medicine Laboratory of Universitas Airlangga. The type of study was explorative research.

\section{Tools}

The tools utilized for this study included binocular microscopes (Olympus), Petri cup, trays, plastics, surgical instruments, tweezers, scissors, mortars, carmine staining sets, disposable syringe, tissue, plastic, object glass, glass cover, $2 \mathrm{~mL}$ microtube, microplate, nitrocellulose membrane, SDS-PAGE chamber running (Biometra), electrophoresis device, trans blotter (Biometra), Whatman paper, shaker, water bath, yellow tip, blue tip, $5 \mathrm{~mL}$ scale pipette, Eppendorf pipette. The main materials used in this study were Whole Worm Extract (WWE), which was from both male and female Toxicara vitulorum and Mecistocirrus digitatus worms, and six Wistar rats. On the other hand, the chemicals required included phosphate buffer saline (PBS, Merck), distillate water (Merck) in 70\%, 85\%, 95\%, glycerin alcohol (Merck), Hung's I, Hung's II (Merck), Carmine seed solution (Merck), acid alcohol, alkaline alcohol, HCl (Gibco cat no. 1640$430-1800)$.

The materials for SDS-PAGE with Biometra devices included Tris aminomethane electrophoresis buffer solution (Sigma cat no. 172-2051), glycine, and SDS (Biorad), acrylamide/bis-acrylamide (Sigma cat no. A-2917), Tris-HCl (Promega 608-274-4330), SDS (Sigma cat no. G-7403), TEMED (Sigma cat no. 7024), Ammonium persulfate (APS) (BioRad cat no. 161-0700, aquadest (Merck), glycerin (Merck), bromfenolblue (Merck), mercaptoethanol (Sigma cat no.M-7154), $\mathrm{NaOH}$ (Merck), $\mathrm{NH}_{3}$ (Merck), citric acid (Merck), formaldehyde (Merck), and acetic acid (Merck). The materials which used for ELISA included $2 \mu \mathrm{g} / \mathrm{mL}$ of $T$. vitulorum antigen, carbonate buffer, $4 \%$ of creamer, washing buffer $\left(0.15 \mathrm{M} \mathrm{NaCl}, 0.05 \%\right.$ Triton $\left.\mathrm{x}-100,0.02 \% \mathrm{NaN}_{3}\right), \mathrm{IgG}$ anti-mouse labeled enzyme alkaline phosphatase, substrate ( $2.7 \mathrm{mmol} / \mathrm{l}$ 4-nitrophenyl phosphate in $1 \mathrm{M}$ diethanolamine; $0.5 \mathrm{M} \mathrm{MgCl}$; $0.02 \% \mathrm{NaN} 3 ; \mathrm{pH} 9.8$ ). The materials needed for the Western Blot test were the SDS-PAGE gel which has been running containing the analyzed protein, transfer buffer (Tris aminomethane, glycine, methanol, and aquades, pH 8.3, ethanol, 5\% blotto, western blue, anti-M. digitatus serum, conjugate (IgG anti-mouse), and Alkaline Phosphatase (AP) substrate (Sigma cat no.AB0300).

\section{Work procedures}

\section{Collection and identification of Toxocara vitulorum and Mecistocirrus digitatus}

Toxocara vitulorum adult worms were obtained from cows' small intestine suffering from toxocariasis. M. digitatus worms were also extracted from cow abomasum obtained from an abattoir in Surabaya. T. vitulorum and M. digitatus worms were cleaned by putting them in Petri cup, which contained 10\% PBS media with a pH level of 7.2 by using anatomical tweezers. The obtained $T$. vitulorum and $M$. digitatus worms were then carefully identified based on morphology to ensure each species (Kusnoto, 2008).

\section{Homogenate preparation and worm protein level measurement of Whole Worm Extract}

Each homogenate was made of four T. vitulorum worms and $100 \mathrm{M}$. digitatus worms, both male and female, manually ground using mortar. Then, the ground worms were put into a tube $(15 \mathrm{~mL})$ and suspended with $5 \mathrm{~mL}$ of PBS. The suspension was centrifuged at 4,000 rpm for 15 minutes. The pellets and supernatants were separated and the supernatant was stored at $2-8{ }^{\circ} \mathrm{C}$. Then, the homogenate protein was concentrated, and the results of protein concentration were calculated based on the standard protein concentration curve (Maehre et al., 2018). The process was made based on the standard concentration absorbance by using a spectrophotometer with $590 \mathrm{~nm}$ wavelength (Bradford, 1976).

\section{Preparation of polyclonal antibodies by Mecistocirrus digitatus}

The polyclonal antibody was prepared by injecting $M$. digitatus homogenate into rats at the dose of $200 \mu \mathrm{g} / \mathrm{rat}$. The injections were subcutaneous with the addition of Complete Freund's Adjuvant (CFA) with the ratio of 1:1 on the first injection, and Incomplete Freund's Adjuvant (IFA) in the booster injections. The re-injection was done three times with two weeks interval times. After the last booster was injected in the sixth weeks, $0.5 \mathrm{~mL}$ of each rat's blood (three blood collection with three days interval) was extracted from the tail to obtain the serum (Kusnoto et al., 2011).

\section{Visualization of Toxocara vitulorum and Mrci.stocirrus digitatus protein homogenate}

The visualization was carried out by using the SDS-PAGE technique with the composition of $12 \%$ separating gel and 5\% stacking gel. Samples of T. vitulorum and M. digitatus homogenate were $15 \mu \mathrm{L}$. As a marker, a protein with a relative molecular period (Mr) ranging from 10 to $245 \mathrm{kDa}$ was utilized to produce the Vivantis. The electrophoresis was set on $100 \mathrm{~V}$ and $40 \mathrm{~mA}$ current for an hour.

\section{Indirect-ELISA}

The $2 \mu \mathrm{g} / \mathrm{mL}$ of $T$. vitulorum antigen was diluted with carbonate buffer (50 mmol/L carbonate, $\mathrm{pH} 9.6)$. Then, the mixture was adsorbed on ELISA microplate at $100 \mu \mathrm{L} /$ well and incubated at $4^{\circ} \mathrm{C}$ overnight. The blocking used $4 \%$ of creamer and was incubated at $37^{\circ} \mathrm{C}$ for an hour. The microplate was washed with washing buffer $(0.15 \mathrm{M} \mathrm{NaCl}, 0.05 \%$ Triton $\mathrm{x}-100,0.02 \% \mathrm{NaN}_{3}$ ) for 3 times. Then, the antibodies were inserted in each well, amounting to $100 \mu \mathrm{L}$ and incubated at $37^{\circ} \mathrm{C}$ for an hour after being washed with a buffer for three times. After that, the microplate was washed 
with washing buffer. Next, substrates were added $(2.7 \mathrm{mmol} / \mathrm{L} 4-$ nitrophenyl phosphate in $1 \mathrm{M}$ di-ethanolamine; $0.5 \mathrm{M}$ $\mathrm{MgCl}_{2} ; 0.02 \% \mathrm{NaN}_{3} ; \mathrm{pH} 9.8$ ) amounting to $100 \mu \mathrm{L} /$ well and was incubated for $10-30$ minutes in the dark room. The absorbance was read by using ELISA-reader at $405 \mathrm{~nm}$ wavelength.

\section{Cross-reaction with western blot}

A running process of the $T$. vitulorum worm homogenate was conducted with SDS-PAGE. Then, the gel containing the protein fragment was removed from the glass plate. After that, it was soaked for 40 minutes in Trans blot buffer and become ready to be transferred to the nitrocellulose membrane. Then, the gel was covered by three sheets of Whatman paper which previously soaked with a Trans blot buffer for 40 minutes and was placed perfectly flat. The transfer process was carried out with $100 \mathrm{~V}$ constant voltage and $40 \mathrm{~mA}$ current for 90 minutes. The nitrocellulose membrane was soaked with $5 \%$ blotto for 60 minutes. The membrane was then washed with TBS, and the nitrocellulose membrane blocking was done by adding 1\% Creamer and 0.05\% TBS-Tween. Next, it was incubated at room temperature overnight. Then, the nitrocellulose membrane was washed with $0.05 \%$ TBS-Tween five times. The nitrocellulose membrane was inserted in a Petri dish, containing anti- $M$. digitatus serum which has been diluted (50 times) with TBS-Tween and was incubated for an hour. It was washed again with $0.05 \%$ TBS-Tween and added with enzyme-labeled antibodies (conjugates) that had been diluted 1,000 times with TBS-Tween. Then, it was incubated at room temperature for an hour. After that, it was washed with $0.05 \%$ TBS-Tween. The membrane was placed on a Petri dish which had been filled with substrate and then incubated at room temperature in the dark room. The Petri dish was then shaken until the color was visible by applying western blue. To stop the process, after enough color was visible, the membrane was placed on a Petri cup containing non-deionized aquabidest (Susana et al., 2019).

\section{Data analysis}

To calculate the Mr protein, a regression formula was applied to determine the Mr protein from running SDSPAGE and Western Blot with the help of standard protein (marker, Vivantis) according to Mishra et al. (2017) . The Mr protein calculation was determined through a regression equation between the Rf (retardation factor) value and the log Mr Data in the marker. The obtained formula could be linear, quadratic, or cubic and could be used to calculate the Mr in the sample by determining the sample Rf value $(\mathrm{X})$ and relative molecular period $(\mathrm{Y})$.

\section{RESULTS AND DISCUSSION}

The anti-M. digitatus serum was administered to the rats. The blood was taken two weeks after the last booster of anti- $M$. digitatus serum and then the serum was tested with indirect ELISA technique. The results of ELISA-reader at $450 \mathrm{~nm}$ wavelength indicated the results of anti-M. digitatus serum with $T$. vitulorum antigen as seen in table 1 .

Based on table 1, it has been indicated that the OD serum value of anti-M. Digitatus with T. vitulorum antigen reached the lowest level by 0.376 , the highest level was 0.530 and the average OD value in all tested samples tested were 0.450. The serum results were visualized with SDS-PAGE while the cross-reaction was demonstrated with Western blot techniques produced bands. After that, relative molecular mass $(\mathrm{Mr})$ calculations were carried out with regression analysis.

The regression calculation analysis on Western blot techniques was conducted through a curve fit analysis to determine the shape of the correlation between $\mathrm{Rf}$ and $\log \mathrm{Mr}$ at the marker. Based on the results of the analysis known that the relationship between the two variables, namely $\mathrm{Rf}$ and $\log \mathrm{Mr}$ was followed by a regression equation. The results of cross-reaction in WWE T. vitulorum worms with anti-M. digitatus serum based on Western blot technique revealed in 12 protein bands as has been demonstrated in figure 1 . Based on figure 1, there was a protein band with $\mathrm{Mr} 10 \mathrm{kDa}$ under marker $11 \mathrm{kDa}$ and above $12 \mathrm{kDa}$ protein. Under marker $17 \mathrm{kDa}$, there was $16 \mathrm{kDa}$ protein. Between marker 17 and 25 $\mathrm{kDa}$, there were no cross-reacting proteins. Between marker 25 to $32 \mathrm{kDa}$, there were protein bands of 26,29 , and 31 $\mathrm{kDa}$ which were thinly expressed. Above the $46 \mathrm{kDa}$ marker, there was a protein which has cross-reaction in $47 \mathrm{kDa}$ which expressed thickest compared to other bands. Between marker $46 \mathrm{kDa}$ and $135 \mathrm{kDa}$, there were cross-reaction proteins in $\mathrm{Mr}$ 47, 59, 68, 89, and $125 \mathrm{kDa}$. Between marker $135 \mathrm{kDa}$ to $245 \mathrm{kDa}$, there was $176 \mathrm{kDa}$ protein crossreaction. T. vitulorum cross-reaction protein with anti-M. digitatus serum obtained 12 protein bands with $\mathrm{Mr} 176,124$, 92, 68, 59, 47, 31, 29, 26, 16, 12 and $10 \mathrm{kDa}$.

Table 1. The result of optical density Mecistorricus digitatus serum with Toxocara vitulorum antigen with indirectELISA on Wistar rats.

\begin{tabular}{|c|c|c|}
\hline First blood collection ( $63^{\text {rd }}$ day $)$ & Second blood collection $\left({ }^{\prime} 6^{\text {th }}\right.$ day $)$ & Third blood collection ( $69^{\text {th }}$ day) \\
\hline 0.396 & 0.434 & 0.507 \\
\hline 0.451 & 0.432 & 0.479 \\
\hline 0.427 & 0.507 & 0.518 \\
\hline 0.411 & 0.449 & 0.483 \\
\hline 0.386 & 0.530 & 0.451 \\
\hline 0.376 & 0.448 & 0.417 \\
\hline
\end{tabular}




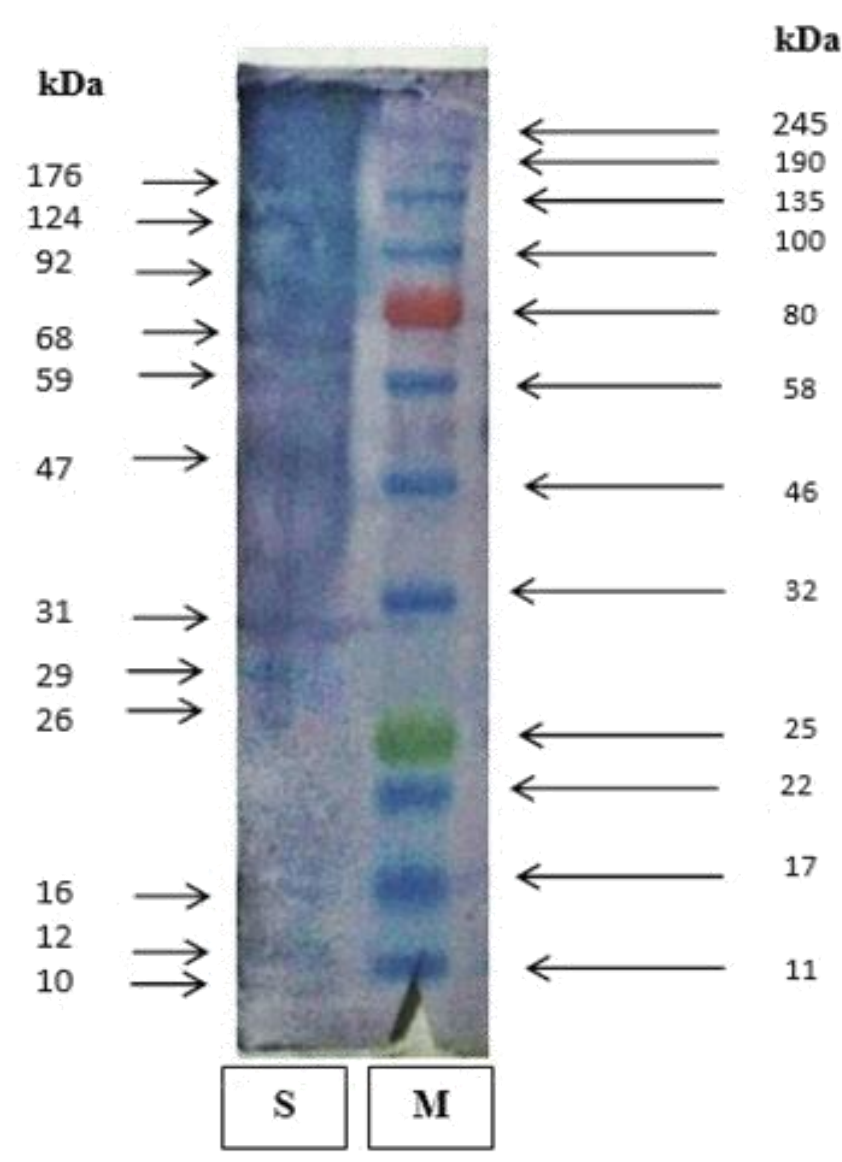

Figure 1. The results of protein cross-reaction from Whole Worm Extract (WWE) Toxocara vitulorum worms with antiMecistocirrus digitatus serum by using western blot techniques. M: Marker, S: Toxocara vitulorum and Mecistocirrus digitatus cross-reaction.

\section{DISCUSSION}

Cross-reaction Protein from WWE T. vitulorum worms with anti-M. digitatus serum by using the Western blot technique obtained 12 protein bands. The T. vitulorum worm protein profile by using Western blot technique indicated 10 similar protein bands between uterine antigen and body wall antigen, i.e., 20.3; 43.6; 46; 53,1; 57.4; 60.3; 66.9; 80,1; 111.3; and $126.3 \mathrm{kDa}$. The Mr values were recorded at 20.3; 24,1; 25.6; 33.7; 37.2; 43.6; 53,1; 57.4; 66.9; $105.5 ; 111.3 ; 126.3$ and $133.9 \mathrm{kDa}$, which were the same protein bands between perienteric fluid antigen and $T$. vitulorum body wall antigen (Jyoti et al., 2011).

The calculation of Mr Protein by using the regression correlation formula might cause relative differences in determination of protein band distance, the length, and the beginning of gel measurement. Therefore, there was a risk of having different difference in actual weight (Kusnoto et al., 2011).

There was cross-reaction between T. vitulorum antigen and Fasciola gigantica antibodies on Mr $133 \mathrm{kDa}$ protein. On the other hand, $143 \mathrm{kDa}$ protein was recognized by Moniezia expansa antibody (Abdel-Rahman and Abdel Megeed, 2000). T. vitulorum WWE antigen with Mr $57.4 \mathrm{kDa}$ was detected as an immune-dominant antigen with anti-T. Vitulorum serum by using Western blot techniques. The antigen $66.9 \mathrm{kDa}$ was found in somatic T. vitulorum antigen. It might be a specific immune-dominant antigen because it was reported not to have a cross-reaction with Haemonchus spp. and paramphistomum epiclitum (Jyoti et al., 2011). Cross-reaction could occur if two antigens have the same or identical epitopes. Moreover, they may have specific antibodies for one epitope that were initially used to bind other unrelated epitopes. Nevertheless, having the same chemical properties could produce cross-reaction (Huebner, 2004). Antibodies which were formed in response to antigens from one parasitic species, could allow reaction with different parasitic species antigens that caused immunological cross-reaction (Noble and Noble, 1982).

Antibodies would be produced optimally when antigens enter the body. Chronic worm infection would be the cause of persistent antigens stimulation that have increased levels of immunoglobulins in immune complexes, circulation and formation. The defense against most of worm infections was performed by activation of Th2 cell (Abbas et al., 2019). Parasites have a larger size than bacteria and viruses, so they contain more antigens in both in terms of numbers and species (Delves and Roitt, 1998).

The existence of cross-reaction in worms was the basis of the polyvalent vaccines development. They were highly crucial components in cross-reaction that were expected to be useful as reagents (Hillyer, 1995). Immunodiagnostic, as an early diagnosis of worm infection had the potential to be deteriorated by non-specific and cross-reaction, due to the 
distribution of antigen epitopes in several worms (Ghosh et al., 2005). Further research is required for purification with affinity chromatographic techniques. In addition, determining the sensitivity and specificity of antigens as candidates for latent toxocariasis immunodiagnosis cases in an adult cow is necessary. This research could lead to chemotherapy with some effective anthelmintic and control of disease in adult cows and calves (Jyoti et al., 2011).

The observations from Western blot indicated high coloring background caused by the unbound antibodies due to lack of washing. Double band visualization was caused by high primary and secondary antibody concentrations bound to specific proteins. Black spots on the blot were caused by antibodies bound to the blocking agent. Meanwhile, the white band on the black blots was possibly caused by too much secondary antibody (Kalanjati, 2011).

The proteins that revealed cross-reaction were not recommended to be used as diagnostic kit material, but they could be developed as vaccine candidates (Abdel-Rahman and Abdel Megeed, 2000). T. vitulorum specific proteins were with $\mathrm{Mr}$ 244, 227, 198, 155, 104, 87, 73, 51, 43, 37, 28, 13 and $11 \mathrm{kDa}$ and because they were not recognized by $M$. digitatus antibodies, Fasciola gigantica, Moniezia expansa, Haemonchus spp. and P. eplicitum, known as specific proteins. The proteins that do not show cross-reaction are specific proteins (Susana et al., 2019). So, it is necessary to conduct an experiment with cross-reaction with other worm species as well as further research that could test the protein specificity. Purification methods will be required to obtain these specific proteins. These specific proteins could be used as a toxocariasis diagnostic kit material.

Purified proteins were better antigens for serological diagnosis than somatic antigens. The existence of crossreaction that occurred in helminthiasis infection could overcome by the use of purified proteins. The use of serological diagnosis techniques on a large scale could be done by using serum obtained from farms, abattoir and experimental animals to determine the level of sensitivity and specificity of the test (Arora et al., 2010).

\section{CONCLUSION}

The cross-reaction between Whole Worm Extract (WWE) of Toxocara vitulorum protein and anti-Mecistorricus digitatus serum resulted in 12 protein bands with each $\mathrm{Mr}$ of 176, 124, 92, 68, 59, 47, 31, 29, 26, 16, 12 and $10 \mathrm{kDa}$. Suggestions for future research include examination of the cross-reactions from other nematodes, cestodes, and trematodes. Therefore, the test specificity will be high. It is necessary to purify $T$. vitulorum proteins to obtain specific band results to be used as diagnostic materials. Further research could determine the level of immunogenicity, antigenicity and sensitivity of proteins. The specificity of each protein could be used as a basis for selecting diagnostic materials.

\section{DECLARATIONS}

\section{Acknowledgements}

Thanks to the authors and all the staff at the Faculty of Veterinary Medicine for their supports and facilities.

\section{Authors' contribution}

Ir.H Kusnoto was the consulting advisor. Desy Meta Anggraini and Suryanie Sarudji appreciated the cooperation for taking care of fishes during the experiment period and helping in the process of experimental work. Ethical issues (Including plagiarism, consent to publish, misconduct, data fabrication and/or falsification, double publication and/or submission, redundancy, etc.) have been checked by the authors.

\section{Conflict of interests}

The authors declared there was no conflict of interests.

\section{REFERENCES}

Abbas A, Lichtman A and Pillai s (2019). Basic Immunology. 6th Edition, Functions and Disorders of the Immune System Printed book (In Indonesia). Pp. 1-336. Available at: https://www.elsevier.com/books/basic-immunology/abbas/978-0-323-54943-1

Abdel-Rahman EH and Megeed KN (2000). Molecular identity of major cross-reactive adult antigens in Fasciola gigantica, toxocara vitulorum and Moniezia expansa. Journal of the Egyptian Society of Parasitology, 30(2): 561-572. Available at: https://pubmed.ncbi.nlm.nih.gov/10946516/

Arora R, Singh NK, Juyal PD and Ghosh S (2010). Immunoaffinity chromatographic analysis for purification of specific diagnostic antigens of Paramphistomum epiclitum. Journal of Parasitic Diseases, 34(1): 57-61. DOI: 10.1007/s12639-010-0011-6

Bradford MM (1976). A rapid and sensitive method for the quantitation of microgram quantities of protein utilizing the principle of protein-dye binding. Analytical Biochemistry, 72(7): 248-254. DOI: https://doi.org/10.1016/0003-2697(76)90527-3

Darmawi D, Balqis U, Tiuria R, Soejoedoeno RD, Pasaribu FH, Hambal M and Daud R (2013). Respons antibodi ayam petelur yang diberikan protein ekskretori/sekretori dan ditantang dengan telur infektif Ascaridia galli. Jurnal Kedokteran Hewan-Indonesian Journal of Veterinary Sciences, 7(2): 145-149. DOI: https://doi.org/10.21157/j.ked.hewan.v7i2.929

De Souza EM, Starke-Buzetti WA, Ferreira FP, Neves MF and Machado RZ (2004). Humoral immune response of water buffalo monitored with three different antigens of Toxocara vitulorum. Veterinary Parasitology, 122(1): 67-78. DOI: https://doi.org/10.1016/j.vetpar.2004.03.013 
Delves PJ and Roitt IM (1998). Encyclopedia of immunology. 2nd Edition, Academic Press. Pp. 1-3072. Available at: https://www.amazon.com/Encyclopedia-Immunology-Peter-J-Delves/dp/0122267656

Fernex EVSD, Alonso-Díaz MA, Gives PMD and Valles B (2014). Reappearance of Mecistocirrus digitatus in Cattle from the Mexican Tropics: Prevalence, Molecular, and Scanning Electron Microscopy Identification. Journal of Parasitology, 100(3): 296-301. DOI: https://doi.org/10.1645/13-377.1

Ghosh S, Rawat P, Velusamy R, Joseph D, Gupta SC, Singh BP (2005). $27 \mathrm{kDa}$ Fasciola gigantica glycoprotein for the diagnosis of prepatent fasciolosis in cattle. Veterinary Research Communications, 29(2): 123-135. DOI: https://doi.org/10.1023/B:VERC.0000047497.57392.8c

Hillyer GV (1995). Comparison of purified $12 \mathrm{kDa}$ and recombinant $15 \mathrm{kDa}$ Fasciola hepatica antigens related to a Schistosoma mansoni fatty acid binding protein. Memorias Instituto Oswaldo Cruz, 90(2): 249-253. DOI: 10.1590/s0074-02761995000200021

Huebner J (2004). Antibody-antigen interactions and measurements of immunologic reactions. Immunol. Immunology, Infection, and Immunity, ASM Press. Washington, Pp. 207-232. DOI: 10.1128/9781555816148

Irnidayanti Y, Darmanto W and Sutiono DR (2018). Western blot analysis and immunostaining for prediction of embryotoxicity in mus musculus. Methods in Molecular Biology, 1797: 497-505. DOI: https://doi.org/10.1007/978-1-4939-7883-0_28

Jyoti, Singh NK and Juyal PD (2011). Identification and characterization of immunodominant antigen (s) of Toxocara vitulorum in buffaloes (Bubalus bubalis). Veterinary Archives, 81(3): 369-378. Available at: https://hrcak.srce.hr/69487

Kalanjati VP (2011). Improving the quality of western blot result. Folia Medica Indones. 47: 108. Available at: http://journal.unair.ac.id/downloadfullpapers-11001\%20ViskasariE\%20_format\%20FMI_pdf

Kusnoto (2008). Antigenesitas, Sensitivitas dan Spesifisitas Protein 27-28 kDa dari Material Excretory-Secretory (ES) Fasciola spp pada Diagnosis Distomatosis Serum Sapi dengan Teknik Indirect-ELISA. Media Kedokteran Hewan, 24(1): 1-8. Available at: http://journal.unair.ac.id/download-fullpapers-01-Kusnoto-Parasit.pdf

Kusnoto, Sudiana S, Sudiana IK and Soedarto (2011). Karakteristik dan Isolasi Protein Spesifik dari Material Excretory-Secretory (ES) Toxocara cati untuk Pengembangan Diagnostik Toxocariasis dengan Teknik ELISA. Jurnal Biosains Pascasarjana, 13(1): 56-65. Available at: http://journal.unair.ac.id/download-fullpapers-Vol\%2013\%20No\%201\%20Jan\%202011-7.pdf

Lastuti NDR, Hastutiek P, Suwanti LT and Chrismanto D (2018). Exploration of Sarcoptes scabiei antigenic protein which play roles in scabies pathogenesis in goats and rabbits. Iranian Journal of Parasitology, 13(3): 466-472. Available at: https://pubmed.ncbi.nlm.nih.gov/30483339/

Maehre HK, Dalheim L, Edvinsen GK, Elvevoll EO, and Jensen IJ (2018). Protein Determination-Method Matters. Foods, 7(5):1-11. DOI: https://doi.org/10.3390/foods7010005

Mishra M, Tiwari S, and Gomes AV (2017). Protein purification and analysis: next generation Western blotting techniques. Expert Review of Proteomics, 14(11): 1037-1053. DOI: https://doi.org/10.1080/14789450.2017.1388167

Mayer G (2010). Immunoglobulins antigen-antibody reactions and selected tests. Microbiol. Immunol. Available at: https://www.microbiologybook.org/mayer/ab-ag-rx.htm

Mufidah N, Ihsan MN and Nugroho H (2013). Produktivitas induk kerbau rawa (bubalus bubalis) ditinjau aspek kinerja reproduksi dan ukuran tubuh di kecamatan tempursari kabupaten lumajang. Journal of Tropical Animal Production, 14(1): 21-28. Available at: https://ternaktropika.ub.ac.id/index.php/tropika/article/view/189/188

Noble ER and Noble GA (1989). Parasitologi: biologi parasit hewan. Gadjah Mada. Printed book. Pp. 1101. Available at: https://onesearch.id/Record/IOS2862.UNMAL000000000000607

Nugroho N (2012). Antigenesitas protein moniezia benedeni dengan serum anti-toxocara vitulorum dengan teknik western blot. Available at: http://repository.unair.ac.id/21499/1/gdlhub-gdl-s1-2012-nugrohonov-21044-4.ABSTRAK.pdf

Rast L, Toribio JALML, Dhand NK, Khounsy S and Windsor PA (2014). Why are simple control options for Toxocara vitulorum not being implemented by cattle and buffalo smallholder farmers in South-East Asia? Preventive Veterinary Medicine, 113(2): 211-218. DOI: https://doi.org/10.1016/j.prevetmed.2013.10.021

Susana Y, Suwanti LT, and Suprihati E (2019). Identification and prevalence of gastrointestinal parasites in beef cattle in siak sri indrapura, riau,indonesia. Indonesian Journal of Tropical and Infectious Disease, 7 (6): 155-160. Available at: http://dx.doi.org/10.20473/ijtid.v7i6.10392

Wickramasinghe S, Yatawara L, Rajapakse R and Agatsuma T (2009). Toxocara vitulorum (Ascaridida: Nematoda): mitochondrial gene content, arrangement and composition compared with other Toxocara species. Molecular and Biochemical Parasitology, 166(1): 89-92. DOI: https://doi.org/10.1016/j.molbiopara.2009.02.012 